Part 1

Life Before Forty 
THIS PAGE INTENTIONALLY LEFT BLANK 


\section{Rocky Mountain High}

AUgust 2, I 990, was to be a memorable day. As I staggered out of bed at our small ranch in Woody Creek, Colorado, and cocked an eye at the early-morning sky, I was relieved: blue as far as I could see. The Rocky Mountains had never looked prettier. The reason for my concern lay in the fact that the president of the United States, George Bush, was due to arrive at our ranch just before noon. Countless hours of planning over the previous two years had gone into this day, and I wanted it to go smoothly, with perfect weather to complement the careful preparation. At 5:00 P.M. the day before, Margaret Thatcher, prime minister of the United Kingdom, had arrived at nearby Sardy Field in Aspen. My wife, Jessica, and I had met her and her husband, Denis, at the airport. Although exhausted from jet lag and hours of flying, Mrs. Thatcher looked perfect: crisp black and white suit, faultless skin, beautiful face, not a hair out of place. No arrival ceremonies had been scheduled. Mrs. Thatcher was to ride with me in the limo provided by the ever watchful Secret Service; Denis and Jessica were to go in a rather less deluxe transport, but after a quick look at his proposed wheels, Denis hopped in the limo with his wife and me, leaving Jessica and our friend Bob Cunningham to return alone. Just as we were pulling away, the mayor of Aspen, Bill Stirling, loped up to the car, tardy and breathless, to present a scroll of welcome. The prime minister accepted it through the window, and we were off, bearing our distinguished visitors to our guest house (coincidentally but appropriately named Parliament House).

This excitement in normally tranquil Woody Creek had its roots in a discussion in late 1988 of how to celebrate the fortieth anniversary of the founding of the unique Aspen Institute, of which I was vice chairman. Albert Schweitzer had helped launch the institute in 1950; we wanted figures of similar stature to come and speak to us, simultaneously 
providing enlightenment and, we hoped, a bit of favorable national attention for the institute.

Early on I had plumped for Mrs. Thatcher, who combined being famous, bright, and articulate with being a woman, a balance that we desired. Jessica, also on the planning committee, felt we should have an American as well and suggested our longtime friend George Bush, who was then president-elect. In one of those coincidences that add sparkle to life, in December 1988 George asked me to be ambassador to Great Britain, making access to the Iron Lady considerably easier. Over the succeeding months, Jessica chipped away at the National Security Council (NSC) chairman, Brent Scowcroft, about pinning down the president, while I, in London, broached the matter with Mrs. Thatcher's brilliant assistant, Charles Powell. In the end, both agreed: Aspen and Woody Creek, its nearby neighbor, would host the president and the prime minister for two days in August.

My early-morning reverie disappeared at about 7:00 A.M. when the phone jarred me back to earth. The White House operator announced General Brent Scowcroft, and I learned some startling news: overnight, Kuwait had been swallowed up by its neighbor Iraq. "Will you cancel the trip?" I asked. "No," Brent replied, "we'll come and make the speech, but we can't spend the night. We'll leave in the early evening."

At I I:40 A.M., the president's small jet (Air Force One, his main transportation, was far too big for Aspen's runway) set down and out leaped George, concerned by the previous night's events but ebullient as always. We hopped in the presidential limo, flown out from Washington, as it is for all of the president's travel. As we pulled away, Mayor Stirling appeared once again outside the car, jogging along, waving a welcome, which he delivered with apologies for his tardiness. Chief of Staff John Sununu, General Scowcroft, British ambassador Sir Antony Acland, and others completed the motorcade, and we sped off to Woody Creek.

Back at the ranch, it was no place like home. The Secret Service had arrived several days before, creating a sterile area within which our guests would be safe. Jessica, aware from experience during presidential visits to London, had warned the Secret Service that murder would be the fate of any agent who hassled our family or neighbors, but even so, security was tight. Secret Service vans lined the dusty road to the house, providing communications, provisions, and a headquarters. They had given all of us "bomb reports," to be filled out after any bombing that might oc- 
cur. We found it a bit ludicrous, as did Mrs. Thatcher's two Scotland Yard officers, who privately poked fun at the expensive and elaborate precautions of their American counterparts. Having never lost a protectee, they could afford to condescend.

The White House Press Corps, numbering perhaps fifty, had arrived before the president and were lined up behind barricades in our garden, ready to extract a comment if they could as the president walked by. (Jessica had warned them not to trample the flowers; they didn't.) Jessica and Mrs. Thatcher waited at the house to welcome George, and shortly thereafter the principals, advisers Brent Scowcroft and Charles Powell, Chief of Staff John Sununu, Ambassador Acland, and I settled ourselves in the living room. The Woody Creek Summit had begun.

The president began the proceedings with a rundown of recent events: the United States was working on a joint statement with the Soviets, condemning the invasion; Jordan's King Hussein had assured Bush that the crisis was abating and was humiliated that his prediction proved wrong; a boycott of Iraq was being organized; Kuwaiti assets in U.S. banks had been frozen.

Mrs. Thatcher, never at a loss for words or reluctant to give advice, said, "This is no time to go wobbly, George," a highly unlikely prospect, since George was not the wobbly type. If Iraq prevailed, she continued, no small state would be safe and Iraqi control of Middle East oil would be unacceptable: "He has to be stopped and we must use all means possible." She, too, had frozen Kuwaiti assets to keep them out of Iraqi hands, and she discussed cutting the Iraqi oil pipelines into Turkey and Saudi Arabia.

The president and the prime minister were seated in twin chairs, a small table between them, the Elk Mountain range providing the distant backdrop. Mrs. Thatcher sat, as always, bolt upright, spine straight as a queen's, an expression of concern on her face. I noted with surprise how often she flattered George. "The Turks," she said at one point, "don't take the big view like you do."

The two had not always had an easy relationship. At their first meeting as equals, a Camp David visit not long after Bush became president (and I, ambassador to the United Kingdom), Mrs. Thatcher had talked without letup, as was her custom. George put up with it, but I sensed he was not amused. At an early opportunity back in London, I confided to Charles Powell, her principal adviser, that perhaps more give-and-take 
might be in order. Whether because of my suggestion or her (or Powell's) intuition, at their next meeting her lectures stopped and the two of them began to get along famously.

The president, as usual, sprawled in his chair, his lanky frame periodically rearranging itself as necessary to make points. He feared the Israelis might hit Iraq with nuclear weapons, thus uniting the shattered "Arab Nation," always more rhetoric than reality. But, he added, "Israel was right and we were wrong" about Saddam and his intentions. He mused on the problems of an invasion of Saudi Arabia, saying such an event would mean a quick Western military reaction. From time to time, he left the room to take calls, one from the Saudi king.

The talk shifted to other subjects, but the rest of us-Scowcroft, Sununu, Acland, Powell, and I-held our peace; it was a Thatcher-Bush dialogue. Gorbachev's cooperation, the near-bankruptcy of the Soviet Norodny Bank, the Vietnamese "boat people" being held in Hong Kong (Mrs. Thatcher warned that she would send them back by force if necessary, a position that was anathema to the president), difficulties presented by Pakistan's nuclear program - all these topics were touched on.

After an hour it was time for the leaders to face the press. There was some speculation on possible questions. "Suppose," someone interjected, "they ask if our soft approach to Iraq has been a failure." Cocking his eyes toward the speaker, Bush said, "At this point, I wouldn't say it's been an outstanding success." We adjourned to the garden and the eager Fourth Estate, which they both handled with ease.

The day went swiftly. Bush made a good speech at the Aspen Institute (the next day Mrs. Thatcher made a brilliant one, perhaps the best I had ever heard). He sneaked away to our mountain pond for an hour of solitary fishing, catching and releasing one rainbow trout. (The leader of his Secret Service protective team told Jessica, "Thank heaven he caught one. When he doesn't, he blames us for scaring the fish away.") He greeted our dinner guests and danced with Jenny Acland, the ambassador's wife, to the music of a Western band that Jessica had found for the event. By 7:30 P.M., it was time for the presidential party to leave. As the big car carried us toward the airport, I pointed out our neighbor Melanie Griffith and her friend Jill St. John, standing outside Melanie's house to see the president pass. Melanie was holding her (and Don Johnson's) new baby. George asked the driver to stop so he could say hello. Fifteen minutes later he was gone, winging back to Washington to begin building the Grand 
Coalition that would free Kuwait and bring George Bush the greatest triumph of his career.

At this point I stop and wonder: what must the reader think of the narrator? It is early to know, I admit. Clearly, he has a good job, ambassador to the Court of St. James's. He knows major figures on the world stage and seems at ease with them. He is a player, albeit a minor one, in great events. Married to a strong woman, he lives in a beautiful place. Can one then conclude that he was to the manor (or manner) born? That he is a gifted, mature politician? If you do, like, man - as my offspring might say - are you ever be wrong! Here's how it happened.

\section{Beginnings}

THE MANOR to which I was born was typical of a Dallas suburb in 1930. It belonged to Maurine Halsell Catto and Henry Edward Catto. The Depression was beginning to bite, and the Cattos were not rich - far from it. Dad managed a stockbrokerage office, Mother looked after their only child, me. If not wealthy, they were well educated. He had gone to New York University, probably because she went to Barnard College, also in New York City.

The market sank, business slowed, and in 1936 Dad took a bold step. He accepted an offer from his brother Jack to come to San Antonio and join not a stockbrokerage but an insurance brokerage firm. Jack, one of Dad's five siblings, had moved to San Antonio years before and was well settled. He had married a beautiful and wealthy widow, Roxana Gage Negley, an owner of the 500,000-acre Gage Ranch in West Texas, and as helping Roxana with the ranch consumed more time, he needed help with his insurance business.

In San Antonio, Dad worked hard and the business prospered. Under Mother's watchful, loving, and sheltering eye, I grew. I went to the local military school, where I was promptly assigned to the awkward squad, a unit that tried with modest success to turn those like me with two left feet into budding Prussians. Every summer we spent at the ranch with Jack, Roxana, their four young - Alfred, Julie, Joan, and Roxana - and Roxana's sister's family, who provided me with some of the give-andtake that an only child lacked. My cousins accepted me as part of the 
gang; they taught me to ride and swim, teased me, allowed me to sneak cigarettes with them, and generally kept me from being hopelessly spoiled. I nevertheless felt the outsider, skinny, athletically untalented, and a bit the poor relation.

Upon graduation from the Texas Military Institute, I went to Williams College in Massachusetts, knowing little about it save that Dad's closest friend had gone there. Pledged to a good fraternity, freed from the paternal thumbs, and as a Texan a bit of an oddity, I prospered. Ties to family, however, remained strong. I wrote home every other day and Mother reciprocated; Dad came up for the fraternity's fathers' day, an unexpected and most welcome surprise. Dates were mostly Texans gone east, though as the years passed, the girls of nearby Bennington College became increasingly appealing (reported to be free spirits and free lovers, but not one of them saw fit to leap into my bed). Academically a slow starter and never a "big man on campus," by senior year I had nonetheless decent grades, many friends, and an inordinate pride of college.

After a two-month graduation-present trip to Europe with two fraternity brothers, I returned to San Antonio and Dad's business, very "Ivy League" in outlook and dress, very highbrow, voguishly liberal politically, and a bit of a snob. Invited to join the "right" clubs, I relished being the escort of the young debutantes, throwing down more whiskey and sodas than was wise in the process. Still, I began to bring new accounts to the firm and to follow my parents in doing civic good works.

A friend once commented that I had the thinnest arms he had ever seen. Stung, I began to sneak off to a gym, a primitive and rather smelly second-story walk-up not far from our office. To my surprise, I stuck with it, with gratifying results. Another friend, seeing me in a bathing suit for the first time in a year, said, "My God, Henry, what's happened to you? Have you lost weight?" I glowed inwardly with pleasure. Encouraged, I took up tennis and later became a dedicated runner and an enthusiastic skier.

Though my parents lived very comfortable lives, their Depressioninduced caution combined with my inertia to keep me living at home. As my twenty-fifth year rolled around, though comfortably settled, I began to take dating seriously: it was time to get married. (Hints about the joys of grandparenthood came from Mother with increasing frequency.) In November 1956, I became engaged to a girl I had dated for more than a year. The following day (after we had told parents and friends), she called 
it off. I was crestfallen and embarrassed, but no amount of further wooing could change her mind: I was again footloose and fiancée free.

Then, a friend's bad luck became my good: Robert Tobin, struck by acute appendicitis, asked me to look after his date for San Antonio's Fiesta. Her name was Jessica Hobby, she was from Houston, and she was gorgeous; blond with sparkling blue eyes, an hourglass figure, and an impish sense of fun. We cut official parties to play chess, we danced like dervishes, we had a glorious time. I was smitten.

Weekend commutes between San Antonio and Houston became commonplace for Jessica and me, though I was intimidated by her family. Her father, William P. Hobby, had been governor of Texas and publisher of the Houston Post. Her mother, Oveta Culp Hobby, had been wartime head of the Women's Army Corps (I am the only man I know whose mother-in-law was a colonel) and Eisenhower's secretary of health, education, and welfare (the second woman ever to serve in a Cabinet post). The governor, 77, was relaxed and charming; Mrs. Hobby, 52, was beautiful and articulate, telling stories of her extraordinary life in a modulated voice from which all trace of her Texas upbringing had been eradicated. I was awed by her, and she viewed this candidate for son-in-law with at best a raised eyebrow. On the other hand, the governor (to Jessica's annoyance and my delight) would bid me Sunday night farewell with "Come back again soon!" Mother and Dad viewed Jessica with affection. As for me? I was deeply in love.

On November 2, 1957, romantic fool that I am, I proposed: "Marriage is like an icy pool: you hold your nose and jump in. How about it?" A week later (a long week), Jessica called me and said yes. I was ecstatic. The wedding, set for February I 5, was large and formal, with an army of attendants. A stroke had disabled the governor, but he recovered sufficiently to give away the bride, the most beautiful sight I had ever seen. After a trip to Acapulco, where we both managed to fall ill, we settled in San Antonio, in a small house that Jessica's talent for interior design made beautiful. Mrs. Hobby offered me a job with the Houston Post at a princely salary. Though flattered, I nonetheless declined; San Antonio and the family firm of Catto and Catto suited us nicely.

By early summer, Jessica began to feel unwell. We feared a stomach ulcer. Dr. Horace Sweet, an old family friend, laughed at that idea: "You're pregnant," he said. Heather was born in April 1959, followed by John, William, and Elizabeth, all within six years. Jessica proved to be a fine 
mother and managed at the same time to become the art critic for the San Antonio Express.

While Jessica spent more or less six years pregnant, I did my insurance work and continued volunteer activities. A principal interest was the United Way. I worked my prospects enthusiastically but lunchtime report meetings were gut-wrenching when I had to stand up and report progress, for I dreaded public speaking. The YMCA and the Symphony Society took time. I headed a committee of volunteers who, disturbed by the plight of thousands of young black soldiers and airmen in the heavily military but segregated city, attempted with remarkable success a year before the Civil Rights Act of 1964 to persuade local hotels, restaurants, movie theaters, and bowling alleys to admit black patrons. And somewhere in my mind there formed an inchoate urge to become involved in politics.

\section{Party of Choice}

TeXAS IN the I940s and I950s was solidly Democratic. The state usually voted for the Democrats in national elections, and Republicans did not even run in local races. Political wars were internecine: conservative Democrats fought liberal Democrats in the political equivalent of mud wrestling. Frequently conservatives would sit on their hands when liberals won control of the national or state party. In 1952 , for example, when Dwight Eisenhower won the Republican presidential nomination, conservative Democratic governor Allen Shivers bolted to Ike and helped him carry the state. That did not, however, mean that Shivers became a Republican. He and his fellow Tories continued to run under the sign of the donkey, to the dismay and disgust of the liberals.

In 1954 I had run for Democratic precinct chairman and had won. Enthralled by Adlai Stevenson's eloquence, I had voted for him in 1952, and did so again in 1956 , albeit with much less enthusiasm.

By the late 1950 , I became interested in a new political phenomenon. Republican activists throughout the state had concluded that one-party dominance of political life was unhealthy and had begun to contest local elections. A Republican actually won a congressional seat in Dallas in 1954. San Antonio Republicans came alive by 1960 and planned a seri- 
ous effort in state legislative races. I decided to join the movement and run, along with four other young business and professional men. In those days, ideological moorings were loose and one could find a comfortable niche in either party.

Jessica was surprised that I had become a Republican, and she was made very uncomfortable by some of the extreme right-wingers who had become active in the party, but she worked hard for me. Her Democratic father's reaction went further. Told I was going to run, he approved. When told I was running as a Republican, he asked if I had lost my mind. In Texas it just wasn't done that way.

Still, I persevered and picked the race I thought would hold the most promise. The Democrats had nominated as legislative candidate an uneducated but shrewd professional gambler named Virgil E. "Red" Berry. In his sixties, Red was a longtime local character. In his earlier days, he had twice been indicted, but never convicted, for murder. He earned a handsome living by operating an illegal gaming house in a vast estate on San Antonio's east side. By running, he hoped to accomplish two things: gain respectability for himself and return legal pari-mutuel betting to Texas.

To me, it looked like a natural. I was young, had a beautiful wife and two small children (Heather had arrived in April 1959 and John in August 1960). Our name was well known, thanks to the family insurance firm's advertising over the years. How could an earnest chap like me lose? Members of the religious community flocked to my side, opposed as they were to gambling. I assiduously courted black voters, for I was a firm believer in civil rights. And I worked hard.

The campaigning theory of the day held that downtown offices were good places to seek votes. I would start at the top of a building and walk down, boldly going into every office, handing out cards and urging a vote for Catto. It was pleasant and the reception was gratifying. But after I had covered the better buildings, I found myself left only with older, less respectable targets - housing loan offices, plaintiffs attorneys, and such.

One day I reached the bottom of the barrel, a seedy building of some twelve stories. Undaunted, I started as usual at the top and plowed through each office. At one point I entered a chiropractor's office. There was no one in the reception room, but having been trained never to be deterred, I boldly opened an inside door. Again there was no one. Taking a deep breath, I marched through a third door into an innermost room. 
It was dimly lit, but I could see it was occupied. "Hi," I said. "I'm Henry Catto, running for the legislature." To my horror, I realized there was a naked woman on a table. The doctor was doing an adjustmentor something - to the woman. The occupant growled, "Get out of here, son," an instruction I did not need, as I bolted for the door, strewing my handout cards behind me.

The race got a lot of publicity. Red and I even had a television debate, which became heated as he dubbed me "fat cat Catto" and I reminded viewers of his checkered past. My confidence proved unfounded, for on election day, I was clobbered, 54 percent to 46 percent. I wrote Red a congratulatory note; he replied in longhand, "If your pretty wife would have ran she would have win." He went on to become state senator and to lay the groundwork for the "return of the ponies," as he put it.

The following year I ran again for the legislature in a special election to fill vacancies in both Congress and the Texas House of Representatives. My teammate, congressional candidate and attorney John Goode, and I ran hard. Former president Eisenhower came to town to help, but we both lost. The old habit of voting the straight Democratic ticket was just too strong.

In spite of this evidence that the people of San Antonio did not want me to serve them, my interest in politics remained keen. I heard that a young oilman had been elected head of the Houston Republican Party, and inasmuch as I was toying with the idea of running for the same post in San Antonio, I called the Houston tyro and asked if we might have lunch. His name was George Bush, and he readily agreed. We ate at the Petroleum Club, high above downtown Houston, and I liked him at once. Although I did not run for county chairman, we became friends and allies in the endless ideological wars that have frequently wracked the Texas Republican Party.

George's wife, Barbara, and Jessica became friends as well. We liked Barbara's intense loyalty and her habit of pulling no punches, and George's wacky, laid-back humor we found impossible to resist. One day the Bushes came to Sunday lunch at our house north of San Antonio (we had by then built a place on a seven-acre tract on a bluff overlooking the distant city). After lunch we took a walk, with son Will, then four, coming along. Tiring of George's shoulders, whereon he had wheedled a ride, he ran about in search of adventure. Suddenly he chirped, "George, what is that?" To my horror, I saw he was pointing at a used condom, left over 
from earlier days, before our property was inhabited. I was at a loss for words, but quick-minded George replied, "Oh, Will, that is an ancient Indian balloon. We'd better leave it where it is." The adults roared with laughter, while Will, satisfied, scampered on.

The 196I election to the Senate of obscure college professor John Tower to succeed Lyndon Johnson (who had become President Kennedy's vice president) gave Republicans a huge boost. I had worked on Tower's campaign, but it wasn't easy. Although he had a rich speaking voice, John developed "presence" only after he became senator. A graduate of the London School of Economics, he was given to pin-striped suits and bowler hats, and he wore a bushy mustache that his party advisers nearly had to throw him to shave. I felt that if Republicans were to succeed, they should court the black vote and I offered to shepherd John's campaigning on San Antonio's east side, where most blacks lived. Though not at all a bigot, he was dubious, fearing damage in segregationist East Texas. Finally he agreed, though he added a caveat: "Let's go there at night so I won't be so obvious."

In the 1964 senatorial election, George Bush ran against the liberalpopulist incumbent, Ralph Yarborough. Though Mexican Americans later became open to Republican courting, in those days they were solidly Democratic, and Republicans harbored a justified fear that some might be tempted to cast more than one vote, given financial blandishment. A law of the time prohibited the use of any language but English at polling places. Knowing a good bit of Spanish, I volunteered for duty as a poll watcher on election day at a precinct deep in the heart of the Spanishspeaking barrio (neighborhood). It was tedious duty until one Mexican American woman official began to give instructions in Spanish, a clear violation of the law. I cautioned her several times, provoking ever greater annoyance on her part. Finally, angered beyond control, she flung a glass of orange soda pop in the face of her arrogant gringo tormentor. As I dried myself, a deputy of the vigorously partisan Democratic sheriff happened to come by. The woman, in machine-gun-rapid Spanish, told the deputy how badly behaved I was, and he arrested me forthwith, driving me to the county courthouse.

By the time we arrived, batteries of Republican lawyers, led by party elder John Goode, waited. The sheriff, fearing that his man might have gone too far, sent me on my way and I was spared durance vile.

Jessica and I went to the 1964 Republican convention in San Francisco 
and saw the fault line that rent the party at its starkest: Governor Nelson Rockefeller, fighting Senator Barry Goldwater for the nomination, was greeted by waves of boos when he arrived to speak. Both of us were disgusted. That event and the Goldwater acceptance speech led us to abandon the nominee in November and quietly vote for Lyndon B. Johnson. (In later life I regretted my apostasy and Goldwater became one of my heroes.)

In 1967 we began to get Potomac fever. Through Jessica's family, we had met President and Mrs. Johnson and during the run-up to Hemisfair, the San Antonio world's fair that opened in 1968, we saw them often. At Johnson's request, Jessica was put in charge of the care and feeding of the press corps when they came to Texas with the president. We and Jessica's family gave a pre-wedding party for Lynda Johnson and Chuck Robb in Houston, and we went to the wedding. On one trip, we spent a night at the White House and flew home with LBJ in Air Force One. It was heady stuff.

During the mid-1 960 a variety of outside activities took up my time. I invested with considerable success in real estate. I wrote a column for the monthly Republican newspaper, gossip mostly but gratifying to the ego. I began polishing my Spanish, looking toward I knew not what. I began seeing a psychiatrist in hopes of getting guidance on ultimate goals in life and help in being an effective person. Rereading notes of those meetings leaves me today with the sad conviction that change in personality or character is woefully difficult: the foolish things I did then (such as fantasizing how I would waste a bully with a well-turned phrase) I still do today, though perhaps with less intensity.

At home, life seemed serene enough. The children suffered the usual illnesses, and sometimes we suffered right along with them. One morning in 1964 I woke up, looked at Jessica, and asked, "What is wrong with your face? It looks swollen." She groggily looked at me and said, "So does yours." We both had the mumps, caught from one of the young.

We bought a small ranch in the nearby Hill Country of Central Texas and enjoyed times there and at my parents' lake home, where Dad taught the elder two of our young to fish and water-ski. But beneath all this tranquillity, I ached for recognition, to stand out from the crowd, to prove myself. Jessica, too, seemed ready for new horizons. 


\section{Boarding the Train}

SIRHAN SIRHAN, in a chaotic act long before chaos theory existed, affected our lives profoundly. Until he murdered Bobby Kennedy in June 1968, the prospects for the Republicans did not seem bright. With one heinous step, Sirhan made Richard Nixon's star rise and, as it turned out, mine along with it.

One of my classmates at Williams was a bright and amusing person named Tom Evans. A lawyer, he worked for the same firm in New York that Richard Nixon later joined, and Nixon took to him. As the campaign began to take form, he played an increasingly prominent role, and when I learned that, I called and told him I would like to help. With the nomination safely Nixon's, Tom asked me to serve as finance chairman of Citizens for Nixon-Agnew and spend as much time as I could in Washington. I accepted, and in September I began to commute to the nation's capital.

Citizens for Nixon-Agnew was an arm of the campaign that organized professional, ethnic, and other groups for endorsements and helped to raise money from them. I put up \$10,000 to get things rolling and went to work. We were headquartered in the Willard Hotel, once elegant but by then vacant, and the staff was mostly young, hardworking, and ambitious. There I met a number of people who were to become friends in future incarnations, among them Lamar Alexander, who later became governor of Tennessee and secretary of education in the Bush administration; John Warner, who would one day marry actress Elizabeth Taylor and be elected senator from Virginia; Dick Scaife, publisher and supporter of conservative causes; and Bill Fitzgerald, later Bush's ambassador to Ireland, and his warm and aristocratic wife, Annelise.

There was great camaraderie, a scent of victory, and occasionally, a sense of humor. Each of the elevators had Nixon posters pasted on the wall, so as we moved about the building we would see the image of the leader and be inspired. One such bore the legend "Nixon's the One." Some wag scribbled on one of them, "Agnew's one, too."

When Nixon did win, I let Tom know I would like to join the administration that was being formed. My interest lay in Latin America, 
thanks to my Spanish and the proximity of my native Texas to Mexico. A sage once said that all ambition should be rooted in reality, but I had not learned that, so my first choice of job was assistant secretary of state for Latin America, which proved laughably out of reach. As a fallback, I put down ambassador to the Organization of American States, the OAS.

My awareness of the OAS stemmed from a visit LBJ had organized for the OAS ambassadors to his ranch in 1967, in support of Hemisfair, the San Antonio-based world's fair. Jessica and I were very much involved and had as our special charge during the visit the United States ambassador to the OAS, Sol Linowitz and his wife, Toni. The Linowitzes were among the most attractive people we had ever met. Under Sol's tutelage, I learned a bit about the OAS and determined that being the U.S. representative would be an exciting challenge.

On March 9 I went to Washington for an interview with Wilmot Hastings, an aide to Deputy Secretary of State Elliot Richardson, and two weeks later I met Richardson himself. It was my first job interview with someone other than my father; I was nervous, but I need not have been. Richardson, wry and laconic, put me at ease, and I felt it was a successful meeting. Shortly thereafter I got a call from a personnel officer named David Lissy and was offered not the top job but the number two position, deputy U.S. representative, with the personal rank of ambassador and a salary of $\$ 36,000$ a year. My goal had been to board the train, and I leapt on-even though it was the caboose. I did not regret it.

\section{Twenty-three Rabbits and an Elephant}

IN JULY we moved to Washington. We had rented the spacious District of Columbia house of former Lyndon Johnson aide Doug Cater and his wife, Libby, for the summer, while waiting for the house we had bought in Bethesda, a Maryland suburb, to be vacated.

My qualifications for the job I was about to assume were minimal. Several years before, as I mentioned, I had resumed the study of Spanish in my spare time. My purpose in doing so had in part to do with the forthcoming Hemisfair '68. Jessica and I were both very involved, she as a member of the executive committee and I as a director. President Johnson was a strong supporter of the fair, and with his encouragement, many 
Latin American countries had come aboard. I thought a thorough understanding of Spanish would be useful and that down the line, if something else came up, I would be prepared.

The early days at my new post were dizzying. The United States mission to the Organization of American States was housed on the fifth floor of the Department of State. The oAs itself was several blocks away, in the old Pan American Union Building, built in 1906 and possibly the most beautiful building in Washington. Not only did I have to learn how the State Department worked but I also needed to meet the vast, impenetrable bureaucracy of the OAS, along with the ambassadors and staffs of the member states. The oAs resembled the United Nations but operated as a regional rather than a global organization. Tasks included matters political, cultural, educational, and developmental. A secretary general orchestrated activities (in my day, a handsome, vigorous Ecuadoran named Galo Plaza), while a council consisting of the representatives of the member countries made the decisions. The United States footed twothirds of the bill but, at least in my time, suffered from Latin resentment of our wealth and power. Galo Plaza once described the oAs relationship with the United States as twenty-three rabbits in a barrel with an elephant. No matter how carefully the elephant moved, a rabbit was likely to be hurt when it did.

My boss was to be Ambassador John Jova, who made the learning process easier and more fun. A career foreign service officer, subtle of mind, quick of wit, and an old hand at the bureaucratic game, he had been ambassador to Honduras when he was chosen to become OAs ambassador. I recall walking through the endless corridors of the State Department with him one day. Our destination, on the opposite side of the building, was on the same floor as our offices, the fifth. Rather than stay on five, however, he guided me up a floor. I asked why. He replied, "Chance meetings can be important, and the people who might be useful to run into have offices on the sixth floor!"

Shortly after my arrival at State I was sworn in as a foreign service reserve officer, but getting the promised rank of ambassador proved difficult. "Bestowing rank of" was a presidential prerogative, and no Senate confirmation was required (though today all ambassadorial appointments go to the Senate). This custom sorely nettled Senator J. William Fulbright of Arkansas, chairman of the Foreign Relations Committee, and each time a president used the privilege, Fulbright rumbled menacingly. Apparently, 
there was fear at the White House that if I were given the rank via this shortcut, other fish then frying before Fulbright would be endangered. Weeks passed with no anointing forthcoming, and I was alarmed and annoyed. Chivvying the department produced no results, so I called Congressman George Bush (he had been elected to represent a Houston district in 1966) and asked him to check.

George's inquiries were met with excuses; dealing with the White House is like swimming through a pot of glue. He was told that the president's letter granting rank had been lost, that Henry Kissinger, head of the National Security Council, had accidentally taken it on a trip (a biographer had described Henry's briefcase as a "black hole"). State Department officials began to get cold feet, and Assistant Secretary for Latin America Charles Meyer suggested that I forget about the whole thing. Then, inexplicably, a letter from the president did indeed arrive, and I was Ambassador Catto. It proved not only gratifying to the ego but also highly useful in dealing with Latin American diplomats, and if Senator Fulbright fulminated, I was blissfully unaware of it.

Office routine varied, and the learning process included meetings with congressmen, briefings at other agencies, and understanding how the State Department worked. Ambassador Jova was a great help, as was a young officer named Leslie Scott, assigned to work with me. Les became a close friend and kept me from pitfalls to which political appointees are subject. One day he suggested we go to the Pentagon for a briefing and I agreed with alacrity.

As I came to know twelve years later, the Pentagon, just across the Potomac from Washington, consists of a warren of corridors, rings, and layers. But as a few days' acquaintance shows, complexity gives way to logic once the architectural code is broken, and finding any office becomes easy. Getting into any office is another matter altogether. Les and I started at the heavily controlled National Military Command Center, escorted by a two-star general named Givens. The briefing took place in a large room with every imaginable kind of screen to show maps and military dispositions. We sat in comfortable, overstuffed chairs, our places marked with signs showing who was to sit where.

The military is a master of protocol and of making people feel important, the theory being that you never know who can turn out to be useful later. (The military services run rings around the Department of State and other agencies when it comes to congressional liaison.) 
The most interesting facet of the visit turned out to be the famous "hot line" between Moscow and Washington. In those days it was a teletype machine. Operators at both ends made sure it worked by sending hourly messages back and forth. One from Moscow arrived during our visit: "If you think the world is flat, just notice that the bow of a ship sailing away disappears before the stern." Right. We replied with a few sentences on Indian history. I asked if our people knew their counterparts. "Not really," the young communicator said. "We don't send personal messages, but we do know, because of the structure of Russian grammar, that one of their operators is a woman and that all are civilians. We do feel a certain community with them because they are the only people in the world that know the importance of our job." Up to that time, the hot line had been used only once, during the 1967 Arab-Israeli war, when some twenty messages passed between LBJ and Soviet leader Aleksei Kosygin.

In many countries of Latin America, the military provides an escalator to the top of the social heap. Aware of this, our military paid court to comrades to the south through an institution called the Inter-American Defense Board. A relic of World War II, when we feared Nazi penetration of Latin America, the board brought senior officials to Washington from all the hemisphere countries. In detailed courses, they studied sociology, economics, and, of course, military science and formed bonds with our people, which became useful later on. Les and I visited the board in October and enjoyed lunch at the Army-Navy Club in downtown Washington, courtesy of two generals and two admirals.

While I learned the ropes, I took more Spanish from the Foreign Service Institute. The main concern at the office, meanwhile, was settling the brutal, brief "Soccer War" between Honduras and El Salvador. Although a soccer game between teams from the two countries caused tensions to boil over, the war that broke out in the summer of 1969 and took some five hundred lives was really a demographic conflict. The border between the two countries, never well defined, allowed relatively free passage for Salvadorans to cross to seek work in the neighboring country. Honduras, large and relatively empty, proved a magnet for enterprising Salvadorans, whose tiny country was the most densely populated in Spanish America. Hondurans resented the competition for jobs and land, and discrimination ensued. The 1969 eruption of hostilities lasted only five days; while Salvadoran troops invaded, the superior Honduras air 
force blew up a refinery and otherwise tried, largely in vain, to cripple the enemy's robust economy.

The real tragedy lay in the disruption of the Central American Common Market. For a number of years, the five Central American countries (Nicaragua, Costa Rica, and Guatemala being the other three) had opened their markets to one another's goods, and the resultant prosperity promised real economic progress. The war ended the market and stunted the prosperity. The OAs, like all the king's horses and men, tried to put things together again, but without success. The best that could be claimed was that the Salvadoran invasion ceased (as much from want of gasoline as from international pressure), withdrawal took place, and endless negotiations about the border began. To this day, the memory of the war vexes relations between the two countries.

All the American states save Cuba belonged to the oAs. (Cuba had been expelled when Fidel Castro's communism became clear. He was not amused. Seldom given to understatement, he said about the organization: ". . . filthy rotten bilge with no honor . . . a court of bandits . . . causes fits of vomiting in my country.") The most important of the three OAs councils was the political, which met frequently in numbingly wordy debate. John Jova covered that beat, while I was assigned to the educational and cultural council. Its meetings were less frequent but no less characterized by garrulity. Key issues included educational projects, technology transfer, and cultural exchange. Contention inevitably centered on why the United States did not do more to help, and why we didn't pay more than the agreed two-thirds of the budget. We, of course, tried to cut our percentage (it was eventually reduced to 50 percent) and tried always to guide our often volatile colleagues into realistic channels, hoping to avoid overlap with UN and other development efforts.

I recall one meeting at which I proposed a development project for the United States, my idea being to show that our country was not perfect and could benefit from Latin help. My colleagues, unsure that I was serious, quickly turned to other matters; money was supposed to flow from north to south, not vice versa.

Foreign aid always sparked controversy. U.S. politicians loved to blast it; recipients felt grudging and resentful at taking it; and administering it created great problems and bureaucratic mayhem. In the 1960 s and earlier, aid was frequently "tied" - that is, recipients had to spend the money with U.S. firms. This arrangement sometimes meant that the developing 
country (political correctness changed "underdeveloped" to "developing") was unable to buy at the best world prices, and loud were the cries when that happened.

In October 1969 President Nixon made a speech on Latin AmericanU.S. relations, and with much fanfare he untied aid. But there was a joker: products made in, say, Brazil, had to be at least 90 percent manufactured there. Thus, for example, a Volkswagen truck essentially made in Germany but then shipped to Brazil for final assembly didn't count; if Brazil wanted to use aid funds for a truck, it would have to buy a U.S. truck. When this mode became clear, the Latins reacted bitterly, complaining that Nixon had a "credibility gap." As the recipient of a good bit of Latin resentment, I brought this matter up at Assistant Secretary of State Charles Meyer's staff meeting, but the AID representativesurprisingly, I thought - was not concerned. Later I came to understand the predicament of the Agency for International Development (AID). AID people had learned from bitter experience that the only way to get their bills passed in Congress was to present them as a sort of subsidy for American business and a jobs program for labor. Untying aid thus became bureaucratically untenable.

Another irritant between north and south arose when Ecuador, whose seas are rich in fish, claimed the right to territorial waters of not just the traditional three miles but two hundred miles. Ecuadoran Navy boats (loaned to Ecuador by the U.S. Navy) began to stop U.S. fishing boats, fine them \$50,000 per incident, and force them to buy \$ I 50,000 licenses. The fine money, incidentally, went to the Ecuadoran Navy; thus there was plenty of incentive for zealous searches of foreign fishing boats.

Members of Congress were outraged and demanded that the U.S. Navy escort U.S. fishing vessels, and then let's see who arrests whom. Congressmen seemed to overlook the possible consequences of such a policy.

First, U.S. investment in Ecuador, always hostage to the threat of nationalization, was substantial. The Ecuadoran government, typically shaky, found itself particularly subject to coup threats from its leftist sector. (The United States, of course, assiduously avoided any actions likely to lead to new communist governments in the hemisphere; the Cold War affected every facet of American foreign policy.) Ecuador had considerable oil, much of it produced by U.S. companies, which meant pressure from American petroleum interests to walk softly. Finally, although the tuna industry was not large in dollar terms, it heavily influenced several 
congressmen. Congress thus passed legislation providing that the U.S. government, not the fishermen, had to pay the fines. Moreover, the United States was required to cut off military aid to any country that played this game and deduct the amount of the fines from U.S. economic assistance!

Ecuador picked up seventeen U.S. boats, fined them some $\$ 800,000$, and then, showing astonishing chutzpah, complained that the United States had violated the oAS rule against economic coercion. It reminded me of the old joke of the boy who murdered his parents and asked for leniency because he was an orphan.

After endless hours of OAS maneuvering, a weasel-worded compromise that satisfied - more or less - both sides was reached. The twohundred-mile territorial limit became, in the end, the norm for developing countries, while the United States went to a twelve-mile limit and later to two hundred miles for resource claims.

Occasionally in our OAS dealings, we tried appealing to common sense and self-interest, and once in a while, the pervasive anti-gringo front cracked. In December 1970 I took the ambassadors of Mexico, Argentina, and Brazil for lunch at the F Street Club, a handsome converted home at 1925 F Street in Washington. My idea was to convince the Latin "Big Three," who with ourselves were the major donors to the OAS, that we should cooperate. After an excellent meal, and a bit of wine, we talked through the afternoon about how to get more for our money from the creaky o As bureaucracy. I felt rapport had been established, but nothing came of the effort.

Perhaps the voice most critical of U.S. policy in Latin America was Senator Fulbright's. As chair of the Foreign Relations Committee and an implacable foe of military aid, he could make any administration official writhe while testifying. In a typical incident in 1971, Deputy Assistant Secretary of State John Crimmins went to the Senate to testify for the U.S. contribution to the Inter-American Development Bank (IADB), an important dispenser of aid. No matter how gamely Crimmins, a very large and imposing man, tried to steer talk to the topic at hand, Fulbright tugged it back to military sales. He felt that Latin countries did not need arms, they needed resources for development. Crimmins retorted that if we didn't sell what the Latins felt sovereignty demanded, the French or others would. "Then let the French contribute to the IADB," Fulbright snorted. No amount of patient explanation that Latin countries felt they could judge better than we the level of arms they needed would convince 
the brilliant, irascible Arkansan; he knew best and that was that. And the dispute outlived Fulbright: a ban on military sales was finally lifted during the Clinton administration in 1997.

\section{Making like Marco Polo}

I waS not exactly well traveled when I went to Washington, my excursions having been limited to Western Europe, Mexico, and Jamaica. Naturally, I was eager to extend my knowledge of the OAS area, and various trips were put on the drawing board. But before any such southerly venture could be organized, an opportunity arose that was too good to miss.

The Israelis had long been active in Latin America, in search of both markets and influence. The United Nations, under Arab pressure, was often the focus of anti-Israeli agitation, and the twenty-plus OAS countries offered potential for Israeli courting. Trips to Israel were a powerful magnet, and when I was invited to go along with a number of oAs colleagues, I quickly said yes - and so did Jessica.

We were scheduled to travel on January I7, 1969, nonstop from New York to Tel Aviv on El Al, the Israeli airline, but El Al's scheduling people are opportunists. When the chance to pick up passengers in Paris arose, we went to get them, schedule be damned.

Israelis reminded me a bit of the Americans of the frontier: no nonsense and, at a certain level, minimum subtlety. (Their diplomats, of course, could be very subtle indeed.) At one point on our flight, a passenger rose before the plane had quite gotten to the gate. The flight attendant wasted no time with the speaker system; she simply pushed him back down into his seat. My first morning in Jerusalem, I was still in bed in a darkened room, de-jet-lagging myself. Suddenly the door flew open, the lights came on, and an annoyed maid chastised me for being a slugabed.

Our tour was impressive. Visits included the Knesset, the Hadassah Hospital, and the wonderful synagogue where Marc Chagall's stainedglass windows illustrate the joys and sorrows of an ancient people. Symposia included a fascinating talk by Dr. Albert Sabin of polio vaccine fame. We saw the ineffably moving Yad Vashem, memorial to the Holocaust, and the Dead Sea Scrolls housed in their teardrop-shaped shrine.

One night several of us dined at a nightclub where part of the enter- 
tainment was a folksinger who wrote his own material. At one point, he dedicated a song to the amputee veterans of Israel's wars. The refrain went:

\author{
You know it breaks my heart \\ To see you've lost a part. \\ But boy you did so well \\ For your country, Is-roy-ell.
}

Everyone clapped, but I didn't know whether to laugh or cry.

Jessica joined me on the twenty-third for excursions, punctuated by visits with Israeli and U.S. officials, to Cana, the Dead Sea, solar power projects, and Tel Aviv. The purpose of the trip was admirably served; certainly the Cattos returned to the United States understanding and admiring the doughty little country. In spite of all odds, Israel was determined like a modern David - to survive and to remain a lively democracy.

Other trips followed. Les Scott and I did a turn through El Salvador, Peru, and Venezuela in May, seeing OAS projects. In September we went to Brazil, Argentina, and Chile. Chile was in turmoil, and Washington was very worried that the just-elected Marxist Salvador Allende would end up another Castro. An oAs meeting was the reason for the trip, and our time was spent trying to get Americans elected to the various permanent committees.

I became tangentially involved in the Chilean political situation as well. At a social event I met a former Chilean journalist named Cristian Casanova, and in a boozy conversation we became amigos. I expressed the hope that Allende would not turn out to be too radical. The next day Casanova invited me to lunch at a grand old Santiago men's club, reminiscent of the British clubs on which it was patterned, for serious talk. He said he had called his friend Allende and told him of having met me. He asked the president-elect if he might use me to send a reassuring message to Washington, which permission Allende apparently gave. Cristian then proceeded to assure me that democracy would remain healthy; the Socialists would only tinker a bit at the edges, such as breaking up the press holdings of the powerful Edwards family and giving them to the press unions. I was not encouraged, but I dutifully reported the démarche to Washington. The administration's hostility was somehow unaffected by my friend's assurances, and icy opposition to Allende lasted until his overthrow by the Chilean army and his suicide. 
In Argentina we called on U.S. ambassador John Davis Lodge, a former actor, a Republican political appointee, and brother of Henry Cabot Lodge, Nixon's 1960 running mate. A big and hospitable man, he nonetheless terrorized his employees, and I developed from him a strong sense of what an ambassador should not be like. Playing that most courtesyconscious of games, tennis, he would call an opponent's shot out when it was a foot inside the line, and his bullying of his partner (the embassy science adviser) made me cringe. He had appeared in the r930s in a movie with Shirley Temple, and he frequently showed the film, forcing his glassyeyed embassy staff to watch him cavort in his salad days. He was wonderfully courteous to Les and me, but we were glad we didn't work for him.

In February 197I I accompanied my leader, Ambassador John Jova, to Lima, Peru, where there was to be an OAS money-pledging session at which the extent of OAS assistance programs would be determined. Such meetings were always elaborate ritual dances. Since the United States matched with two dollars each dollar the Latin Americans put up, our interest was keen. In their turn the Latins, always short of cash, did not want to get out ahead of one another and an "after you, dear Alphonse" routine became a ritual.

Jova had a cousin in Lima, a Peruvian aristocrat who invited us to her home for a drink and then to dinner at the Tambo de Oro, a fine restaurant. I learned a bit about Peruvian social attitudes when one of the guests, chic and arch, criticized the wife of the U.S. ambassador to Peru, Toby Belcher. She asked me, "Why does Mrs. Belcher spend all that time working in Lima's slums? If she makes them too nice, more people will move in and the problem will get worse."

Life at us /OAS, as our office was designated at the Department of State, was far from all travel and glamour. The average day of dealing with OAS problems could be paralyzingly boring. In the committee meetings where much of the work took place, endless arguments over fine points of Spanish grammar and syntax were the rule. The English speakers - that is, those from the Caribbean islands and ourselves - would glance at each other and roll our eyes in frustration when these sessions bogged down; together we constituted an informal biracial linguistic alliance spurred by a desperate wish to get on with it.

Latin sensitivities, a constant worry, arose all the time. The oAs holds an annual meeting of foreign ministers called the General Assembly, and the question of how much time the U.S. secretary of state would spend with his Latin American colleagues invariably created tensions. At the 
I970 assembly, Chile and Colombia did not send their foreign ministers, so sure were they that Secretary of State William Rogers would not spend any time at the meeting. Rogers fooled them; he spent two full days and charmed all concerned.

I had a constant flow of visitors from Texas to my office. Indeed, I felt that I was a sort of fourth congressman for San Antonio as people came by with requests. One concerned funding for a new federal office building in San Antonio. The city fathers thought it a sure thing until a congressman from Michigan named Gerald Ford put a hold on the money, hoping to siphon it off for his own district. I went to see a friend at the Office of Management and Budget (OMB) and learned that we were indeed in trouble and that only intervention by Senator John Tower of Texas at the highest level could save the project, which eventually went down the drain.

One day an oAs employee came by and told me that the organization was really run by a cabal of Cubans and Jews and that he couldn't get anything done. I eased him out of my office as best I could, though I gladly would have booted him in the rump.

On a typical day, I was called on by a man asking for U.S. support to create a new foundation to improve health conditions in developing countries; by a Haitian embassy acquaintance wanting a U.S. residence permit; and by a New York advertising woman wanting to work for the president. Why me? Perhaps I radiated vibes of goodwill - or of an easy mark.

George Bush sent a couple of men by to see me, Messrs. Tye and Holloway, whom I suspected Bush wanted to be rid of. Some years earlier, Tye had gone to Bolivia with an idea for commercial use of tailings, tiny pieces of tin that are normally just waste. The government, doubting that his idea was viable, gave him a concession, but sure enough, the plan worked and he soon had a small going concern. Alas, in one of the innumerable coups that marked that country's history, the victorious new government rewarded some of its supporters by giving them the company. Mr. Holloway, Tye's attorney, asked me, quite seriously, "Why don't we just change the Bolivian government?" I tried to explain that those days were over and that the U.S. mission to the OAS was not the place to seek redress in any case. They left, and I heard no more of the matter.

A pleasant aspect of life at the State Department's Latin American bureau consisted of occasional retreats, during which the country officers, area directors, our OAS mission, and others would retire for two days of 
meetings and brainstorming about problems in the hemisphere. Henry Kissinger once said that no one above the rank of assistant secretary had time to think, given the vast and time-consuming problems of simply running the bureaucracy. He was probably right. Unfortunately, when we lesser mortals did get together to think, we frequently got it wrong. In the fall of 1970 , such a meeting took place at Airlie House, in rural northern Virginia. The principal result was a consensus that U.S. policy toward Cuba was sure to fall apart soon and that it needed reassessing. Keen young analyst that I had become, I solemnly concurred with this prediction, which twenty-three years later had yet to come true.

\section{The Social Tightrope}

SOCIA L LIFE looms large in Washington, but it is not all fun and food. It is hard work as well. Contacts are made and business gets done in the guise of a dinner party. Careers are made or ruined by a whispered exchange at a crowded reception. As a newcomer to Washington and to this intriguing, important game, I would have been dubbed terminally naive but for one thing - Jessica. Raised in a political household in both Washington and Houston, she caught on quickly. When she entertained, she did so with flair, and we soon found ourselves invited to all manner of functions.

We had a head start in another area. President Johnson's ranch was near San Antonio, where we had lived, and the press corps that covered his activities when he was at the ranch was billeted in that colorful city. Since Jessica had been asked by the president to look after the press, we became friends with many of the top reporters, among them Max Frankel of the New York Times, Bob Pierpoint of CBS, Richard Valeriani of NBC, and Hugh Sidey of Time. When we moved to Washington, they provided a warm welcome and an entrée to a vital part of the political scene. Max and Tobi Frankel had children who more or less matched ours in age, and we spent many a weekend with them. Bob Pierpoint and Pat were close as well. Bob had been a student in Sweden, spoke Swedish, and knew many Swedes. I soon developed the naive idea that he would make a good ambassador to that country, with which our relations were quite strained. My näiveté lay not in my judgment of Bob's ability but in the likelihood 
that the Nixon administration would appoint a journalist of independent mind to anything. Indeed, during the Watergate days, the president was asked if he was angry with Pierpoint about a story Bob had done on CBS Evening News. Nixon snapped illogically, "To be angry at someone, you have to first respect them."

Sightings of Nixon were rarer than seeing a prothonotary warbler, at least at my level of government. My feelings about the president were mixed. I wanted desperately to like and admire him; to be troubled by him cast doubt on our whole Washington adventure. For the most part, I approved of his actions. I noted in my daybook in November I97 I some pros and cons of the president. The pros, to me, included getting out of Vietnam with honor (I later concluded the cost was far too high); setting up the Environmental Protection Agency; proposing his imaginative Family Assistance ideas; opening China; negotiating the strategic arms limitations; and expanding the national parks. The cons included what to me seemed dreadful appointments, like Carswell to the Supreme Court, and the way he handled the shooting of the students at Kent State University. I felt strongly that a Cabinet member should have been sent to the funerals, but when I suggested that to aide Peter Flanigan, he scoffed.

Seeing the president was beyond hope, I feared, but I nonetheless dropped hints to Bush and others that we would dearly love to be invited to a state dinner at the White House. Miraculously, in October 1970 an envelope addressed in calligraphy appeared, and we, Latin Americanists, found ourselves bidden to a dinner for President Nicolae Ceausescu, the ruthless dictator of Communist Romania. It may have been "out of area," but we of course accepted, and it turned out to be a memorable evening.

A White House dinner, always exciting, presented a sore temptation to Nixon to gild the lily. As the Nixons and Ceausescus came into the East Room to greet the guests, four flamboyantly uniformed trumpeters blew a fanfare, and as the band played "Hail to the Chief," the presidents and their wives marched solemnly in. "Hail to the Chief" is quite enough to tingle the spine, and it has a certain democratic dignity, but trumpeters in Middle European costumes struck me as too much. When we were presented to the presidents, Nixon asked Jessica about her mother, with whom he had served in the Eisenhower administration. Extremely cordial, the president asked me about the oAs, proving that he had studied his guest list carefully and knew who was who.

After all the guests had been met, we filed into the state dining room, 
and as Mr. Lincoln looked benignly down from his portrait above the fireplace, we found our places. Nixon insisted on seating his guests banquet style, along E-shaped tables. That meant very stiff protocol, with all people of rank ghettoized, while probably more interesting guests without rank sat on the periphery. It was clumsy, and Jessica and I approved when Gerald Ford became president and switched to round tables.

During the toast after dinner, often a boring event, President Nixon referred to "the People's Republic of China." I had been woolgathering during the platitudes of the toast, but when he uttered those words, I nearly fell off my chair. Never had Richard Nixon called the PRC anything but "Red China" or "Mainland China" at best. I didn't know what it meant, but I knew something was up, and I excitedly talked to Jessica about it after dinner. Sure enough, it turned out to be part of the elaborate courting dance that the United States and China were going through, preparatory to Nixon's historic trip to China that ended decades of loathing and war. Romania, a friend of China, was playing a role as intermediary.

Ceausescu's toast, amazingly, had a flash of humor. He said, "I want to assure the people of the United States, they have nothing to fear from Romania," and then, slyly digging at the United States for its worldwide role, he added, "Next time I am in the United States I hope all Romanian troops will have returned to Romania and all U.S. troops are home in America." After dinner, soprano Anna Moffo gave a staggeringly beautiful recital, greeted the Ceausescus in Romanian, and sang a song for them in their language.

I had another glimpse of Nixon in action, as both man and politician, in May of the next year. The White House Press Corps salutes itself each year at a lighthearted white-tie banquet to which the president often comes and trades barbs with the reporters. In 1970, Max Frankel, head of the New York Times Washington bureau, was to be honored as the recipient of the prestigious Clapper Award. As Max strode to the podium to accept, Nixon, at the head table, turned away seemingly deliberately, snubbing Max. (The Times had been particularly critical of the administration.) John Connally, by contrast, got up, slapped Max on the back, and congratulated him. Nixon and the press seldom were at less than swordpoint, but Connally knew that snubbing was dumb.

Among our greatest friends, to be sure, were George and Barbara Bush. By 1969 the Bushes were veterans of the capital, George having 
been elected in 1966 and returned without opposition in 1968. In October they gave us a welcome party at the Alibi Club, an old, unobtrusive building on I Street, whose walls were lined with caricatures of members, while other memorabilia crowded every surface. It was the quintessential Washington insiders' party: journalists, senators, and administration offcials in a relaxed atmosphere, conversation informed and off the record.

A larger party in November was also typical. Chief of Protocol Emil "Bus" Mosbacher and his wife, Pat, had a dinner at Blair House, the president's guest house across Pennsylvania Avenue from the White House. Wall- to-wall ambassadors, the gathering fairly glittered in the nineteenthcentury elegance of the handsomely furnished old mansion. Jessica sat between the ambassadors from Iran and Malaysia, while I was bracketed by the latter's wife and the Uruguayan ambassador's wife. It was our first exposure to Iran's remarkable Ardisher Zahedi, later to become a friend and our host for many an evening. After dinner, a singer accompanied by a harpsichordist, both in period costume, performed eighteenth-century music into the small hours. The Bushes were there, and I was not the only one to get a bit restless; George had the fidgets and that glazed look in the eye that meant "Will this never end?"

On November 6 I dropped by George's office and learned momentous news: he had determined to run again in 1970 for the Senate. His 1964 campaign against Senator Ralph Yarborough had been hard-fought, but he was swept away in the Goldwater debacle. In 1970, with no presidential election and Yarborough looking weak, he decided to go for it again. I wasn't too sanguine about his chances; Republicans were still a rare breed in Texas, and though the liberal Yarborough was out of step with the Texas outlook on many issues, he was nonetheless a Democrat and an incumbent.

A totally unforeseen event reshuffled the political deck. A rather conservative former congressman and shrewd businessman from Houston, Lloyd Bentsen, beat Yarborough in the May 2 Democratic primary. George had handily beaten a right-wing opponent and I called with congratulations. Elated by Yarborough's defeat, he felt the little-known Bentsen would be an easier target. In contrast, Jessica was not so sure, feeling that many conservatives would be comfortable with Bentsen and dubious about having two Republican senators. Her concerns turned out to be prescient.

Jessica and I both became involved in the campaign. In September we 
had a party at the F Street Club in Washington, a fundraiser for George and Robert Taft Jr. running in Ohio. President Nixon was eager to help and invited a select few to the White House to underline the importance of these races. And while I traveled in Latin America, Jessica stepped in and, with some help from my father, had a very successful fundraiser in San Antonio. I had warned her not to expect much; off-year races in Texas frequently don't generate much juice. Still, she determined to raise the then very substantial goal of \$ro,ooo; she exceeded it. Money was not the only object at such functions, and Bush, as always, radiated goodwill and charm. Pic Swartz, a Democratic friend who attended, told Jessica afterward, "I just want you to know the party was terrific and George Bush is the most impressive politician I've ever met."

On November 3, election day, we were in Houston, to visit Jessica's mother (her father had died in 1964) and be with the Bushes that election night. I smelled defeat, probably less from political acuity than from the ingrained pessimism of a 1960s Texas Republican. As the evening wore on, gloom settled in. About nine o'clock the CBS crew gave the race to Bentsen, but on learning that no votes from Houston, strong Bush country, had been counted, they rescinded their prediction. Our elation was short-lived, however, and even the hoped-for big victory in his home city couldn't save him.

We were sad; the Bushes were crushed. Back in Washington, we went to a party November 7 at columnist Charles Bartlett's, a "cheer up the Bushes" effort by him and his wife, Martha. It didn't work. Even speculation that Nixon might give him a Cabinet post, such as Treasury, failed to lift George's spirits. Jessica called on Bar at home shortly thereafter, and found her even more down than George was. She said she had simply wept for forty-eight hours, and that it was like a death in the family: there is no appeal.

Buoyed by support from Bar, his friends, and his family, George's natural ebullience soon reasserted itself. I went to lunch with him on November 19 at the House of Representatives dining room, and no fewer than five waitresses stopped by our table to commiserate with him. He clearly wanted an administration job, and Nixon seemed inclined to offer one. We speculated on his future path. He ruled out NASA or the Small Business Administration; his eye was on the Cabinet, particularly Treasury.

That bubble burst on December I4. I was at my office when Jessica 
called, urged me to sit down, and told me that John Connally had just been named Secretary of the Treasury. It was, to a Texas Republican, truly unbelievable. In 1968, in spite of having told Texas Republican chairman Peter O'Donnell that he favored Nixon, Connally had supported Hubert Humphrey, albeit lukewarmly, and as a conservative Democratic governor he represented everything Texas Republicans were trying to expunge. That he be clasped to our bosom took the breath away and proved once more than the ways of the White House were mysterious indeed. Political gossip had it that Nixon admired Connally's strength, forcefulness, and charm; perhaps he had in mind replacing Agnew in 1972. What did it mean for our hero, Senator John Tower? No one outside I600 Pennsylvania Avenue knew for sure.

In the end, George Bush landed on his feet, in spite of the apparent setback: the president named him our ambassador to the United Nations, with Cabinet rank.

Jessica's political intuition came to the fore. If Connally was to be among us, we might as well make the best of it, erstwhile enemy or not, and she began to plan a party in the Connallys' honor. A welcome by Texas Republicans would signal to John that the past was forgotten (sort of) and would indicate to our stunned colleagues back home that they should toe the line.

The Connallys readily agreed; March I 5 was set as the date, the F Street Club the venue. Jessica arranged a star-studded guest list (including older brother Bill Hobby), a trio to enliven the party with music, special tablecloths, and an elegant menu.

The event proved her efforts worthwhile. The black-tie crowd was in a festive mood, my after-dinner toast was warm in its welcome, and we anticipated John's response with pleasure. Sure enough, the silver-tongued and silver-headed former governor proved to be at his best. A superb extemporaneous speaker, he talked of having known the Cattos and of having hunted at their ranch. He praised the senior Hobbys for their government service. Then he said, "And in this generation, we have their offspring, Bill and Jessica, one so smart, one so beautiful ...” Jessica, gorgeous and full of the spirit of the moment, broke in: "Which is which, John?" There was a roar of laughter, including from Connally himself.

Washington social life, by nature always in flux as the government cast came and went, had nonetheless a certain structure bestowed upon it by a number of rather grand women, permanent fixtures who stayed on 
through Republican and Democratic administrations. Most of them were shrewd, highly intelligent ladies, and they played a role by bringing together the political stars in creative combinations. The grandest of them all when we got there was Alice Roosevelt Longworth. Daughter of Theodore Roosevelt and widow of longtime House Speaker Nicholas Longworth, she was quick of wit and often funny. Though Jessica and I met her only once, we were fascinated. With remarks like "If you don't have anything nice to say, come sit next to me," she was much in demand until her death in her nineties.

One story, possibly apocryphal, about Mrs. Longworth tickled me greatly and illustrated her spirit. In 190I, when President McKinley was assassinated and her father became president, the young Alice was asked sympathetically how she felt, her interlocutor expecting her to confess shock or horror. Her reply: "Ecstatic!"

Susan Mary Alsop - both with her husband, columnist Joseph Alsop, and, after their divorce, alone - was (and is) one of the best. So was Lorraine Cooper, wife of Kentucky senator John Sherman Cooper. Mrs. Cooper took us under her wing as well. Arch and stylish, she could be terribly funny. At a December 1969 dinner party in the Coopers' Georgetown home, she told of deciding to go to see a soft-core porn film then much in vogue, I Am Curious-Yellow?. She invited the beautiful Evangeline Bruce, wife of the distinguished former ambassador David Bruce and a fine hostess herself, and Mrs. Longworth to join her. Mrs. Longworth volunteered to have the driver of her ancient RollsRoyce pick up tickets in advance so they would not have to stand in line and-God forbid - be seen. What they did not count on was that the line to enter the theater exceeded that to get tickets, so the three women had to stand, very much revealed to public view, the Rolls-Royce in the background matching their slow pace toward the door.

At one Cooper party I was listening to the immaculately dressed, acerbic, and elegant Alsop hold forth to a small group that included the wife of the postmaster general, Winton "Red" Blount. The hors d'oeuvres consisted of bite-size tomatoes, and Mrs. Blount, rapt at Alsop's comments and always the lady, bit into one rather than popping it whole into her mouth. A jet of bright-red juice shot out, splattering Alsop's pristine white vest. He simply could not believe, at first, that it was an accident. The horrified perpetrator tried to clean him up, but he retired to his nearby home for a change of clothes. 
Social life can be trying for the hosts. In May 197I we were invited to a dinner by Margo and Gil Hahn, president of the D.C. City Council. Margo, a consummate party giver, a superb cook, and someone I enjoyed talking with, pulled me aside shortly after the guests arrived. She demanded breathlessly, "Do you know what I've done?" I admitted to ignorance and she confessed, "I have invited Art Buchwald and Joe Alsop to the same party!" In a brief cause célèbre of the time, Buchwald had written a play in which he made fun of an Alsop-like character. Happily for Margo, there were no punches between the two columnists, but a lively exchange took place between Henry Kissinger and Mary McGrory, an outspoken and very liberal Washington Star columnist. Kissinger, a frequent target of Mary's barbs, always tried to win over his critics. Arriving late with Ambassador Yitzhak Rabin from Israel (who was to be assassinated in 1995), he sat at our table for dessert and, his deep rumbling voice tuned to please, asked Mary when she was going to invite him to dinner. McGrory, whose social graces were not improved by alcohol, snapped, "When you have the last American out of Vietnam!" Henry gave up.

In January 1970 we were invited to a gala at the Shoreham Hotel, given by the fabled hostess Perle Mesta for Ethel Merman, who had played a Mesta-like character in the Broadway musical Call Me Madam. Mesta, who at one point was LBJ's ambassador to Luxembourg, apparently did not earn her fame as a Washington hostess for the small, candlelit kind of dinner. The Merman bash was far too crowded, with poor champagne, and in a hotel ballroom at that. Ethel did, however, sing "There's No Business Like Show Business," proving that her voice and presence still could dominate an audience.

A hostess of a different sort, fellow Texan and Lady Bird Johnson's press secretary Liz Carpenter, was very kind to us. She and her husband, Les, had dinners at which the focus was on issues. Rather than following the usual form, of polite conversation with the woman on your left followed at the "turning of the table" by more talk with the dinner partner to your right, Liz would call guests to order, throw out a topic, and expect everyone to comment. She was quick-witted. When longtime Democrat John Connally became a Republican in the midst of the Watergate scandal, Liz cracked, "It's the first time in history where a rat swam toward a sinking ship." At Liz's table you had fun.

Washington life benefits from the diplomatic corps. Most countries 
send their best here, and the result is an enriched social scene. Jessica and I learned this early. For example, our Israeli trip created a natural tie with Israeli ambassador to the United States Rabin and his smart, handsome, tennis-playing wife, Leah. A visit to this country by Israeli's top Latin expert, Netanel Lorch, gave me an excuse to have him to lunch, with John Jova, Ambassador Rabin, and Max Frankel of the New York Times to leaven the mix.

We gathered at the $1925 \mathrm{~F}$ Street Club, and Rabin, later to be elected Israel's prime minister, spun a theory about the failure of a recent American raid on a North Vietnamese prison camp. The idea had been to release prisoners. None were found and the administration, especially the Pentagon, was left with egg on its face.

Rabin demurred, "I don't know whether you Americans think the way we do, but here is the way I would have figured it out if I had been in the president's place."

In the first place, he mused, what were your problems? Your problems were two: Number one, you wanted to convince the North Vietnamese that you were capable of a very vigorous strike near their capital and you wanted to indicate to them that you still had plenty of sting left even though you were withdrawing. Number two, you wanted to indicate that you didn't like having your reconnaissance planes shot down and you really wanted to speak to your constituency in Hanoi. Well, that's fine, except that speaking strongly to your constituency in Hanoi involved speaking also to people who didn't want to see the war escalated. If you did anything very dramatic, you'd most likely get Senator Fulbright and all the people of his ilk furious and start a new great tidal wave of dissent that would hurt you in other areas. So how could you combine these problems and overcome them? The answer was try to rescue the prisoners. That had been the thing that caught the interest of the American people and what could be better than to try a rescue? Well, that was fine, except there was a problem there too, and that problem was, suppose you went in and before you could get them out, their captors murdered most of them or they were killed in the fighting; that was an ever-present danger. I knew because we had been involved in it and you had to have inside help to make sure that the people you intended to help didn't get hurt.

And, he continued, the answer to that, since you probably didn't have anybody inside the prison camp, was to hit a prison camp that was al- 
ready vacant. Clearly, you got credit with the American people for trying a rescue. You scared the very daylights out of Hanoi because they were unwilling to admit that it happened and they would have gladly let it pass and never made a peep about it because it was humiliating. And finally, you completely neutralized Fulbright and people of his type. Who was to blame? Well, you blamed it on some faceless intelligence type who goofed things up, and the result was a very happy situation.

Max thought the idea preposterous, and I was inclined to agree. Yet the next day Senator Fulbright himself, quoted in the Washington Post, said he thought we knew the camp contained no prisoners.

Perhaps the most elegant dinner that Jessica and I attended during our OAS days took place in the New York City Fifth Avenue apartment of New York governor Nelson Rockefeller and his wife, Happy. We had gone to New York at the invitation of the Bushes and had stayed at their official UN residence, a flat in the Waldorf Towers. Although Rockefeller had been Jessica's mother's deputy at the Department of Health, Education, and Welfare in Eisenhower's administration, we did not know them well and were pleased to be invited. Jessica looked particularly lovely as we gawked at the Matisse and Léger murals, the most beautiful Picasso we had ever seen, and the fabulous view of the city and Central Park.

The guests included Nelson's brother David and his wife, Peggy, Mr. and Mrs. Russell Baker, and the Douglas Dillons (Dillon having been secretary of the Treasury in the Kennedy administration). When we met the former secretary, he looked a bit puzzled and then a light turned on. "I just today voted against you," he said to Jessica. She was totally mystified as to what he was talking about and showed it. He went on: "You were an independent candidate for AT\& T's board, and it fell my lot to vote our proxies against you. If I had seen you first, I might not have!" Dillon was a director of AT\&T. Eventually we found out that a strange corporate gadfly we had met in Washington had nominated Jessica for the board, without her knowledge or consent. But Dillon gained two fans that night.

Rockefeller, a superb host and a fine politician, put all his guests at ease, with gracious toasts and amusing stories. At a House hearing at which he reported on a trip to Latin America, he was lectured to by a particularly priggish congressman from New York named John Bingham. How could you, the indignant legislator asked, appear in public with the brutal dictator of Haiti, Papa Doc Duvalier? Nelson responded, “Jack, 
put yourself in my position. There I was, representing the president of the United States with the president of a country we have relations with, even though the relations are cool, and he says come out on the balcony and greet the crowd, and it's very hard not to go." Bingham primly asked, "Did you have to smile?" Rocky replied, "A politician with three hundred fifty thousand smiling, waving people in front of him? Who wouldn't smile?"

Rocky sometimes played straight man. At a party at Joan and Tom Braden's in I97 I, he made a toast to Israeli ambassador Rabin. Carried away on a wave of goodwill and gemütlichkeit, he said, "The people of Israel are the most industrious, attractive, and grandest people I know of and I want to drink a toast to their health and the success of their country."

Ambassador Rabin rose to reply: "Thank you, Governor. Coming from you, the Governor of New York, it is doubly appreciated. You surely know the Jews well, since you control more of them than we do!"

Everyone roared, Rocky most of all.

\section{D.C. Family Life}

OUR LIVES were not all glamour and cavorting with the great. Indeed, as I go over my calendars, I am gratified to note how many things we did with the children and how many nights we spent quietly at home.

Having bitterly resisted the idea of leaving San Antonio, the children adapted surprisingly quickly to the Washington area. Heather attended the local public school in Montgomery County, John and Will went to Sidwell Friends School, and Isa enlivened the scene at Norwood School. The pleasures of a real winter entranced all of us. Our pool froze over, and someone borrowed a pair of skates from next door. No sooner was it determined that the ice would hold than Jessica was off to the store. Soon everyone had skates, and we went to the nearby c\&o canal for some serious skating. A nonskater myself, I looked out at this brightly clad group and felt I had stumbled into a Pieter Brueghel painting of sixteenthcentury Holland.

A hard winter yielded a gorgeous spring, and we were all awed by the color and variety of it. Spring in South Texas has its beauties and, above 
all, its scents, but for flamboyance, Washington can't be bested. First the forsythia in March dots the neighborhoods with vivid yellow. Azaleas in pink and red appear everywhere, and in recent years, thanks to Lady Bird Johnson, the tulips she had planted are bright enough to cause the viewer to squint. April's cherries and dogwoods hypnotize any newcomer. Fiveyear-old Isa, seeing bursts of blossoms fall from a cherry tree in a breeze, said, "Look, Mother, it's snowing flowers."

Our rotund and beloved mutt, Ginger, gave birth to nine-count them, nine-puppies. Our excitement gave way to a race to see who could park them with friends fastest, but two stayed with us to make up for the loss of Pancho, a giant, gentle, aged Belgian shepherd that had to be put away.

One day I pulled car pool duty and overheard seven-year-old Will and his classmate discussing strength. The friend commented on his own father's physical prowess, and I waited expectantly for Will to counter with an illustration of my own. Instead, I heard him say, "Aw, that's nothing. My grandfather is so strong he can even lift my sister." Ten-year-old Heather was not amused; I was.

One night I came home early and we decided to eat with the children for a change. Our habit had been to eat late, after feeding the young, so this represented a bit of a departure from the usual. Heather, seeing places set at the table for us, asked with disgust, "You're going to eat with us? Weird." As time passed, the "weird" became the usual as I clung to the quaint idea that family meals provide quality time together. For all the inevitable squabbles and sulks, I still think it worthwhile, though occasionally hard on the digestion.

Our house in Bethesda suffered from poor planning such that the easiest way to the backyard, pool, and neighboring homes led through our bedroom. This meant little privacy for Jessica and me, so occasionally we would sneak off to the guest room for a moment alone. On one such day, sure that we had escaped the children, we retreated, locked the door, and got ready for a bit of solitude. How futile! About five minutes after the click of the lock, a great pounding on the door began. It was John with news of an emergency: "Mom, come quick!" he demanded. "Isa's throwing perfume on the throw-up."

Jessica's main activities focused on raising the young, running the home, and promoting my career in a thousand subtle ways (her political acumen and people savvy far outstripped mine). On top of all that, she 
devoted time to volunteer efforts as well, such as working with Marg McNamara, wife of former secretary of defense Robert McNamara, in the literacy-promoting organization Reading Is Fundamental.

Marg, incidentally, had told us an interesting story as we hiked one day in Colorado. Recalling her husband's early days as secretary of defense, she said the conventional wisdom of how John Connally got to be secretary of the navy - that LBJ forced him on President Kennedy - was wrong. When McNamara agreed to leave Ford Motor Company, where he was CEO, and come to Washington, he told the president he wanted to choose his own team at the Defense Department. Kennedy concurred, but shortly thereafter he began to push Franklin Roosevelt Jr. for secretary of the navy. An interview with Roosevelt turned McNamara off, and he began to look elsewhere. Someone, she thought Sam Rayburn, suggested Connally, who quickly sold himself. McNamara called Kennedy in Florida to inform him. The president concurred and said there was someone else there McNamara would want to tell, handing the phone to LBJ, who learned for the first time that his longtime ally would be joining the administration. 
THIS PAGE INTENTIONALLY LEFT BLANK 